\title{
Using a Hydrologic Model to Assess the Performance of Regional Climate Models in a Semi-Arid Watershed in Brazil
}

\author{
Carlos A. S. Santos ${ }^{1,2, *}$, Felizardo. A. Rocha ${ }^{1}$, Tiago B. Ramos ${ }^{2}{ }^{\circ}$, Lincoln M. Alves ${ }^{3}$, \\ Marcos Mateus ${ }^{2}$, Rodrigo Proença de Oliveira ${ }^{4}$ (D) and Ramiro Neves ${ }^{2}$ (D) \\ 1 Instituto Federal da Bahia, Av. Amazonas-351, Zebelê, CEP 45030-220 Vitória da Conquista, Bahia, Brazil; \\ felizardo@ifba.edu.br \\ 2 Centro de Ciência e Tecnologia do Ambiente e do Mar (MARETEC), Instituto Superior Técnico, \\ Universidade de Lisboa, Av. Rovisco Pais, 1, 1049-001 Lisboa, Portugal; \\ tiagobramos@tecnico.ulisboa.pt (T.B.R.); marcos.mateus@tecnico.ulisboa.pt (M.M.); \\ ramiro.neves@tecnico.ulisboa.pt (R.N.) \\ 3 Centro de Previsão de Tempo e Estudos Climáticos/Instituto de Pesquisas Espaciais - CPTEC/INPE, \\ São Paulo, Brasil; lincoln.muniz@gmail.com \\ 4 Civil Engineering Research and Innovation for Sustainability (CERIS), Instituto Superior Técnico, \\ Universidade de Lisboa, Av. Rovisco Pais, 1, 1049-001 Lisboa, Portugal; rodrigopoliveira@tecnico.ulisboa.pt \\ * Correspondence: carlos.amilton@ifba.edu.br or carlos.amilton@tecnico.ulisboa.pt
}

Received: 3 December 2018; Accepted: 10 January 2019; Published: 18 January 2019

\begin{abstract}
This study assessed the impact of climate change on the hydrological regime of the Paraguaçu river basin, northeastern Brazil. Hydrological impact simulations were conducted using the Soil and Water Assessment Tool (SWAT) for 2020-2040. Precipitation and surface air temperature projections from two Regional Climate Models (Eta-HadGEM2-ES and Eta-MIROC5) based on IPCC5-RCP 4.5 and 8.5 scenarios were used as inputs after first applying two bias correction methods (linear scaling-LS and distribution mapping-DM). The analysis of the impact of climate change on streamflow was done by comparing the maximum, average and reference (Q90) flows of the simulated and observed streamflow records. This study found that both methods were able to correct the climate projection bias, but the DM method showed larger distortion when applied to future scenarios. Climate projections from the Eta-HadGEM2-ES (LS) model showed significant reductions of mean monthly streamflow for all time periods under both RCP 4.5 and 8.5. The Eta-MIROC5 (LS) model showed a lower reduction of the simulated mean monthly streamflow under RCP 4.5 and a decrease of streamflow under RCP 8.5, similar to the Eta-HadGEM2-ES model results. The results of this study provide information for guiding future water resource management in the Paraguaçu River Basin and show that the bias correction algorithm also plays a significant role when assessing climate model estimates and their applicability to hydrological modelling.
\end{abstract}

Keywords: climate change; Paraguaçu River Basin; semi-arid region; SWAT model; Eta-HadGEM2ES; Eta-MIROC5; correction bias

\section{Introduction}

The Intergovernmental Panel on Climate Change (IPCC) Fifth Assessment Report (AR5) [1] provided an overview of projected impacts on water resources for different regions of the globe. These are likely to have profound implications on human populations, and are already being reported throughout the world [2-5]. The Brazilian semi-arid region, one of the poorest rural communities in the country with 24 million inhabitants ( $12 \%$ of the national population), is particularly vulnerable to 
this phenomenon [6-8]. In this region, the lower availability of water resources reported over the last few years has affected agricultural activities, the economy, and society in general due to an extensive drought $[9,10]$. Climate change projections for this region suggest a substantial temperature increase, rainfall reduction, and the occurrence of more extended periods with consecutive dry days; these that will no doubt exacerbate the water scarcity problem.

The integrated assessment of regional climate and hydrological models is increasingly being performed worldwide to study the impact of climate change on water resources [11-16]. Regional Climate Models (RCMs) provide dynamic downscaling of Global Climate Model (GCM) results and higher-resolution scenarios. They are the first step towards assessing the vulnerability of water resources to climate change and adaptation needs. On the other hand, hydrological models are commonly used for estimating streamflow, but can also ease the assessment of RCMs performance by integrating the complex spatial and temporal dynamics of several meteorological variables in a reduced number of river cross sections, with precipitation being the most important.

Several studies demonstrated that different factors can lead to uncertainty when evaluating streamflow under climate change. In general, this uncertainty is associated with GCM initialization, downscaling techniques, future emission scenarios, hydrologic model parameterization, climate variables (temperature and precipitation) inputs, and bias correction methods $[12,14,17,18]$. Krysanova et al. [19] showed that a good hydrological modeling performance for the historical period increases confidence in projected climate change impacts and decreases the uncertainty related to hydrological modeling estimates.

In this paper, we recognize the importance of an adequate model performance when estimating the impact of climate change on local water resources. Santos et al. [20] already calibrated and validated the Soil and Water Assessment Tool (SWAT) [21] for simulating streamflow in the Paraguaçu watershed following the hierarchical scheme proposed by Klemeš [22]. The objective of this study is now to support or reject the hypothesis that a well-calibrated hydrological model can: (i) assess the performance of regional climate models; (ii) evaluate the methods used for bias correction of RCMs precipitation estimates; and (iii) assess the impacts of climate changes on streamflow under different climate scenarios. The daily precipitation and maximum and minimum daily surface air temperatures projections from the Eta regional climate model $[23,24]$ forced by two global climate models (HadGEM2-ES [25] and MIROC5 [26]) under different emission scenarios were used to represent climate change projections for 2020-2040. The hydrological cycle was then simulated with the calibrated SWAT model for the Paraguaçu River Basin with impacts being analyzed by comparing the simulation results under different scenarios. The results of this study can provide valuable information for guiding future water resource management in the Paraguaçu watershed as well as in other arid and semiarid regions of the world.

\section{Materials and Methods}

\subsection{Study Area}

This study was conducted in the Paraguaçu River Basin, Bahia state, northeastern Brazil $\left(11^{\circ} 17^{\prime}-13^{\circ} 36^{\prime} \mathrm{S} ; 38^{\circ} 50^{\prime}-42^{\circ} 01^{\prime} \mathrm{W}\right)$, (Figure 1). The drainage basin is $55,317 \mathrm{~km}^{2}(10.14 \%$ of total state area), with an altitude range of 0 to $1800 \mathrm{~m}$. According to the Köppen classification, the climate in the Paraguaçu watershed varies from semi-arid (BSh) in the central part (67\% of the area) to equatorial (Af) in the west and southeast. Consequently, annual precipitation ranges from less than $600 \mathrm{~mm}$ in the central region up to $1400 \mathrm{~mm}$ in the west and southeast. The study area was here limited to the upstream of the Paraguaçu River just before the interception of its main tributary (Figure 1), covering an area of $37,900 \mathrm{~km}^{2}$. 

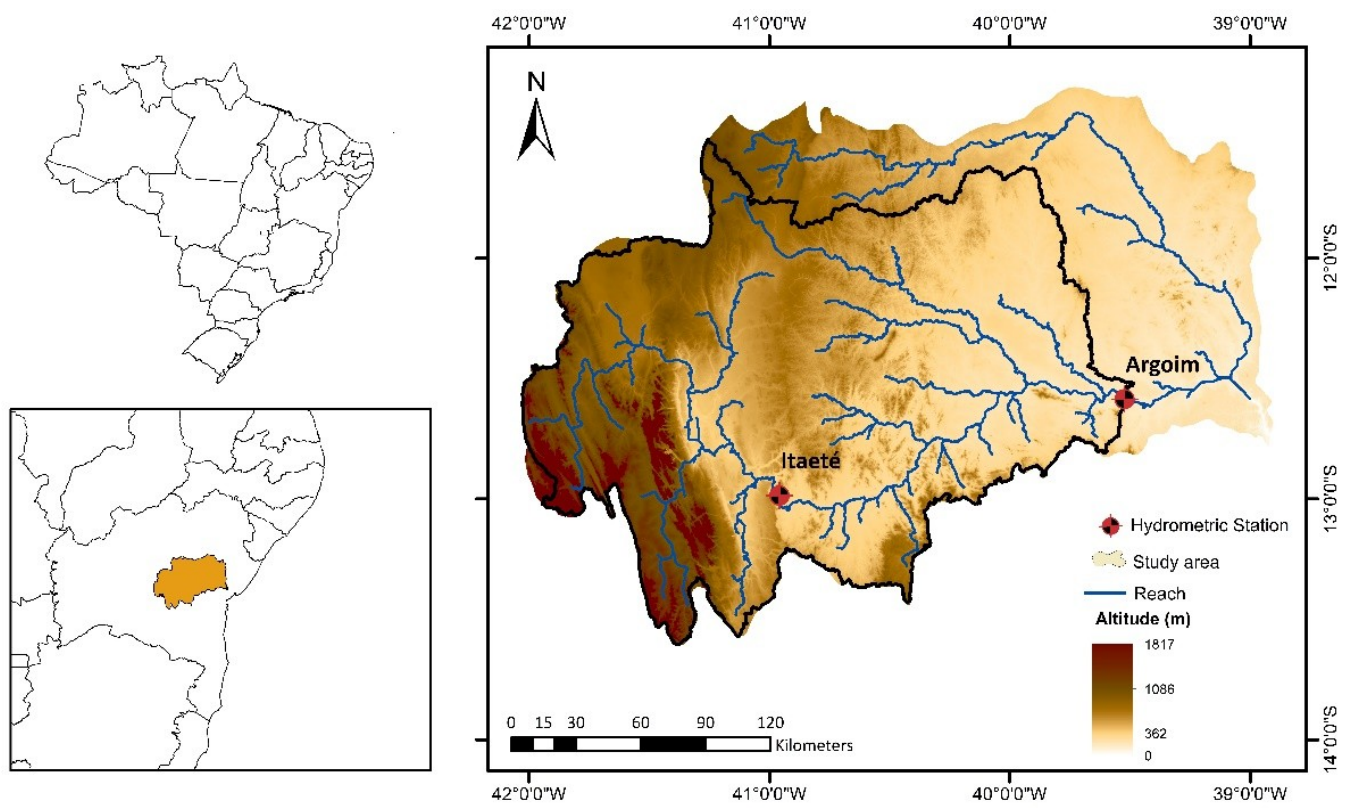

Figure 1. Location of the Paraguaçu River Basin, Bahia state, northeastern Brazil.

\subsection{Soil and Water Assessment Tool}

\subsubsection{Model Description}

The Soil Water Assessment Tool [21] is a physically-based, semi-distributed, catchment scale hydrologic model, widely used for simulating the effect of climate and land management on the hydrological regime of the catchment [27]. The hydrologic cycle is based on the computation of the daily water balance, as follows [28]:

$$
\mathrm{SW}_{\mathrm{t}}=\mathrm{SW}_{\mathrm{o}}+\sum_{\mathrm{i}=1}^{\mathrm{t}}\left(\mathrm{R}_{\text {day }}-\mathrm{Q}_{\text {surf }}-\mathrm{ET}_{\mathrm{a}}-\mathrm{Q}_{\text {deep }}-\mathrm{Q}_{\mathrm{gw}}\right),
$$

where $\mathrm{SW}_{\mathrm{t}}$ and $\mathrm{SW}_{\mathrm{o}}$ are the final and initial soil water contents $(\mathrm{mm})$, respectively, $\mathrm{t}$ is the time period (days), $R_{\text {day }}$ is the precipitation (mm), $\mathrm{ET}_{\mathrm{a}}$ is the actual evapotranspiration (mm), $\mathrm{Q}_{\text {surf }}$ is the surface runoff $(\mathrm{mm}), Q_{\text {deep }}$ is the water drained into the deep aquifer $(\mathrm{mm})$, and $Q_{g w}$ is the return flow $(\mathrm{mm})$, all on a given day i. The overall water balance is computed for hydrologic response units (HRUs) consisting of homogeneous land-use, soil, and slope characteristics [29]. Potential evapotranspiration $\left(\mathrm{ET}_{\mathrm{p}}\right)$ rates are estimated following the Penman-Monteith approach [30], with rates being then reduced based on soil water availability to obtain $\mathrm{ET}_{\mathrm{a}}$. $\mathrm{Q}_{\text {surf }}$ is calculated from daily $\mathrm{R}_{\text {day }}$ using a modification of the Soil Conservation Service Curve Number (SCS-CN) method [31]. $Q_{\text {deep }}$ is obtained by combining a storage routing technique and a crack-flow model. Lateral flow is simulated using a kinematic storage method. A detailed description of the model is provided by Neitsch et al. [21].

\subsubsection{Model Setup, Calibration and Validation}

Santos et al. [20] applied the SWAT model for simulating streamflow in the Paraguaçu watershed. There, the study area was divided in 69 sub basins and 1906 HRUs based on the digital elevation model (DEM), land use and soil maps available for the region (Figure 2). The DEM was extracted from the Shuttle Radar Topography Mission (SRTM), presenting a spatial resolution of $30 \mathrm{~m}$. The land-use map was obtained from GlobCover 2009 [32]. The soil map was produced by Empresa Brasileira de Pesquisa [33], with the soil physical and chemical properties being collected from the literature [34-37]. Precipitation data was obtained at Agência Nacional de Águas (ANA), while the remaining weather data was from Instituto Nacional de Meteorologia (INMET). Xavier et al. [38] meteorological grid of 
variables was also used to complement weather information and more accurately describe the high rain spatial variability of rainfall in the region.
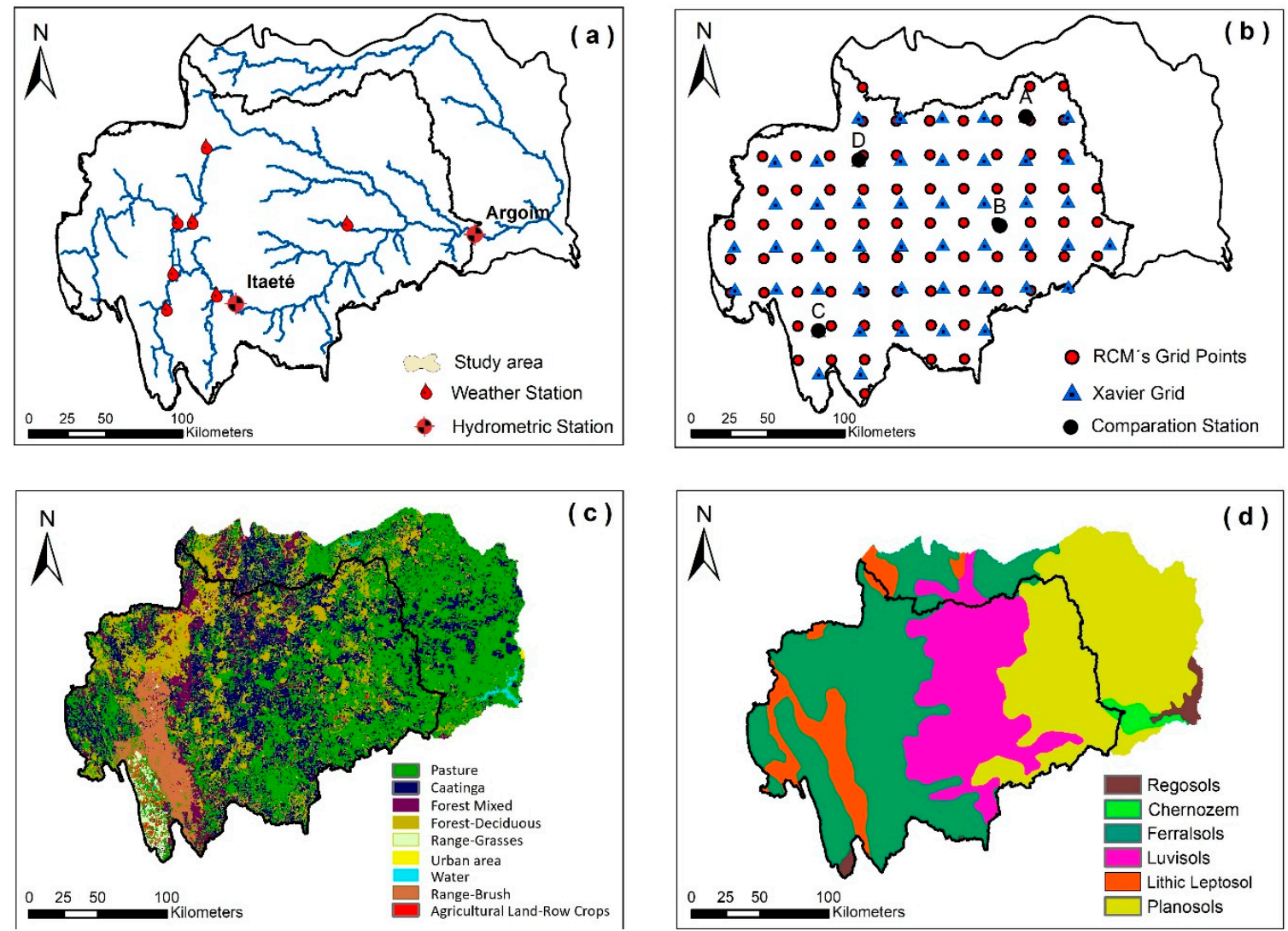

Figure 2. (a) Localization of weather and hydrometric stations; (b) Regional Climate Model (RCM) and Xavier et al. [38] grid points; (c) land-use map; (d) soil map.

This study followed Santos et al. [20] in performing calibration and validation of the SWAT model by comparing simulated and observed monthly streamflow at two additional hydrometric stations: Itaeté and Argoim (Figure 2). Daily discharge data at these stations were collected at Agência Nacional de Águas (ANA). Two time periods were selected for this analysis: calibration was performed for 1989-1996, while validation was for 1997-2005. The simulation ran from January 1985 and included four years of model warm-up (1985-1988). Daily values of the water balance were integrated into the monthly averages.

The goodness-of-fit indicators adopted for comparing SWAT model simulations of streamflow with measured data were the coefficient of determination $\left(R^{2}\right)$, the Nash-Sutcliffe model efficiency (NSE), the percent bias (PBIAS), and the root mean square error observations standard deviation ratio (RSR). The $R^{2}$ indicates the degree of linear relationship between observed and simulated data, with values close to one indicating better performance. The NSE is a normalized statistic that determines the goodness of fit and ranges from $-\infty$ to 1 . Values close to 1 indicate a perfect match, while values close to 0 or negative indicate that observations are a better description of reality [39]. The PBIAS measures the deviation of model simulations from the measured data, with values above or below zero indicating under- or overestimation of the observed data, respectively [40]. The RSR is a scaling/normalization factor that ranges from 0 to infinity, with smaller values indicating better simulation results [40]. The calibration/validation performance of a SWAT model was also evaluated following Moriasi et al.'s [40] criteria. 


\subsection{Climate Change Projection}

\subsubsection{Regional Climate Model and Scenarios}

The dynamical downscaling of the RCM Eta from two GCMs (MIROC5 and HadGEM2-ES) of the Fifth Assessment Report (AR5) dataset [24] provided climate projections for two different Representative Concentration Pathways (RCPs): the RCP 8.5 and RCP 4.5 W.m ${ }^{-2}$ radiative forcing scenarios. The first RCP is the most pessimistic and results in a global average warming at the end of 21st century of from 2.6 to $4.8^{\circ} \mathrm{C}$, while the second is an intermediate scenario representing global average warming between 1.1 and $2.6^{\circ} \mathrm{C}$ [41].

The Eta-MIROC5 and Eta-HadGEM2-ES divide the year into 365 days and 360 days, respectively. The time series of the Eta-HadGEM2-ES model was thus converted to a 365-day calendar prior to its use in the SWAT model. This conversion was performed using a linearly technique proposed by Bosshard et al. [42]. The regional model Eta-MIROC5 and Eta-HadGEM2-ES have a resolution of $20 \mathrm{~km}$ in the horizontal direction and 38 layers in the vertical for the domain area of South and Central America [23]. The variables simulated by both RCMs were the daily precipitation and daily maximum and minimum temperatures, which were used to assess the potential hydrological impacts in the Paraguaçu catchment.

\subsubsection{Bias Correction}

As the estimates of the RCMs for the control period may not agree with the observed data, a correction is usually introduced to minimize the existing bias. This correction is based on the differences between observed and historical simulated values [43]. Maximum and minimum temperature values thus were corrected using an additive term based on the difference of long-term monthly mean observed and simulated data. For each variable, a set of 12 grids, one for each month, were produced from the observed and simulated monthly values. The addends were assumed to remain static even for future conditions. The following equation was used to correct temperature values [18]:

$$
\mathrm{T}_{\text {corr }}(\mathrm{d})=\mathrm{T}_{\text {sim }}(\mathrm{d})+\left[\mu_{\mathrm{m}}\left(\mathrm{T}_{\mathrm{obs}}(\mathrm{d})\right)-\mu_{\mathrm{m}}\left(\mathrm{T}_{\text {contr }}(\mathrm{d})\right)\right],
$$

where $\mathrm{T}$ is the temperature daily $(\mathrm{d})$ values, $\mu_{\mathrm{m}}$ is the long-term monthly mean, $\mathrm{T}_{\text {corr }}$ are the bias corrected values, $\mathrm{T}_{\text {sim }}$ are the RCMs simulated values, $\mathrm{T}_{\mathrm{obs}}$ are the observed values, and $\mathrm{T}_{\text {contr }}$ are the simulated values during the historical (or controlled) period.

Two methods were evaluated to correct the precipitation values. The Linear Scale method (LS) uses a multiplicative factor to adjust the simulated monthly mean values to the observed monthly mean weather values. The correction factors were assumed to remain static even for future conditions. A set of 12 grids, one for each month, was computed from the observed and simulated monthly mean precipitation values and the following equation was used [18]:

$$
\mathrm{P}_{\text {corr }}(\mathrm{d})=\mathrm{P}_{\text {sim }}(\mathrm{d}) \times\left[\mu_{\mathrm{m}}\left(\mathrm{P}_{\mathrm{obs}}(\mathrm{d})\right) / \mu_{\mathrm{m}}\left(\mathrm{P}_{\text {contr }}(\mathrm{d})\right)\right],
$$

where $P$ represents the precipitation daily $(\mathrm{d})$ values.

The purpose of the second bias correction method (DM) is to correct the distribution of the RCM simulated estimates to agree with the distribution of the observed values. The gamma distribution (Equation (4)) with shape parameter $\alpha$ and scale parameter $\beta$ is often assumed to be suitable for the distribution of precipitation events [18]:

$$
\mathrm{f}_{\mathrm{r}} \mathrm{x} \mid \alpha, \beta=\mathrm{x}^{\alpha-1} \times \frac{1}{\beta^{\alpha}} \times \mathrm{e}^{\frac{-\mathrm{x}}{\beta}} ; \mathrm{x} \geq 0, \alpha, \beta>0 .
$$

The cumulative distribution functions (CDFs) were constructed for both daily observed and RCM simulated precipitation value (1985-2005) within a specific month. The value of the RCM-simulated precipitation for a given day $d$ within month $m$ was taken from the empirical CDF of the RCM 
simulations together with its corresponding cumulative probability. Thereafter, the value of precipitation of the same cumulative probability was located on the empirical CDF of observations. Finally, this value was used as the corrected value for the RCM control baseline (1985-2005), as follows [18]:

$$
\begin{aligned}
\mathrm{P}_{\text {corr }}^{*}(\mathrm{~d}) & =\mathrm{F}_{\mathrm{Y}}^{-1}\left(\mathrm{~F}_{\mathrm{Y}}\left(\mathrm{P}_{\mathrm{corr}}(\mathrm{d}) \mid \alpha_{\mathrm{corr}, \mathrm{m},} \beta_{\mathrm{corr}, \mathrm{m}}\right) \mid \alpha_{\mathrm{obs}, \mathrm{m},} \beta_{\mathrm{obs}, \mathrm{m}}\right) \\
\mathrm{P}_{\mathrm{scen}}^{*}(\mathrm{~d}) & =\mathrm{F}_{\mathrm{Y}}^{-1}\left(\mathrm{~F}_{\mathrm{Y}}\left(\mathrm{P}_{\mathrm{scen}}(\mathrm{d}) \mid \alpha_{\mathrm{corr}, \mathrm{m},}, \beta_{\mathrm{corr}, \mathrm{m}}\right) \mid \alpha_{\mathrm{obs}, \mathrm{m},}, \beta_{\mathrm{obs}, \mathrm{m}}\right),
\end{aligned}
$$

where $\mathrm{F}_{Y}$ and $\mathrm{F}_{\mathrm{Y}}^{-1}$ are, respectively, the gamma cumulative distribution function and its inverse,

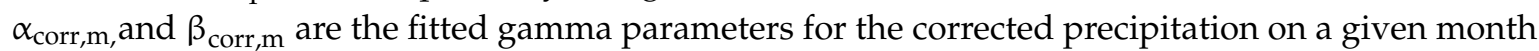
$\mathrm{m}$, and $\alpha_{\mathrm{obs}, \mathrm{m},} \beta_{\mathrm{obs}, \mathrm{m}}$ are the corresponding fitted gamma parameters for observation. More detailed information on this methodology is provided by Teutschbein and Seibert [18].

\subsubsection{Evaluation of Bias Correction Methods}

The bias correction methods applied to RCM estimates of temperature and precipitation were evaluated by applying the following statistics to the monthly streamflow estimate: average annual flow, maximum and minimum average monthly flow, and the 10 percentile (Q10) and 90 percentile (Q90) values of the average monthly flow. Additionally, the Wilcoxon's nonparametric hypothesis test was used to compare the data series.

\section{Results and Discussion}

\subsection{Model Calibration and Validation}

Table 1 lists the default and calibrated parameters used during the water balance simulations for the Paraguaçu River basin. These were first tested in Santos et al. [20], who calibrated/validated the SWAT model for simulating streamflow in the Andaraí, Fortém, and Iguaçu sub-basins of the Paraguaçu watershed, and applied here now for assessing the accuracy of streamflow predictions in Itaeté and Argoim.

Table 1. Calibrated parameters and range of values for the study area.

\begin{tabular}{cccc}
\hline Parameter & Description and Units & Default & Calibrated Value \\
\hline GW_DELAY & Groundwater Delay (days) & $0-500$ & $31-365$ \\
GW_REVAP & Revaporation coefficient $(-)$ & $0.02-0.2$ & $0.02-0.2$ \\
GW_RCHRG_DP & Deep aquifer recharge $(\mathrm{mm})$ & $0-1$ & $0.05-0.25$ \\
Mgt1_CN2 & SCS runoff curve number for moisture condition II (-) & $35-98$ & $45-78$ \\
HRU_SLSOIL & Hillslope length $(\mathrm{m})$ & $0-150$ & $0-85$ \\
SOL_AWC & Available water capacity of the soil layer $(\mathrm{mm} / \mathrm{mm}$ soil) & $0.075-0.40$ & $0.1-0.30$ \\
SOL_Z & Soil depth $(\mathrm{mm})$ & - & $500-3000$ \\
SOL_K & Saturated hydraulic conductivity $(\mathrm{mm} / \mathrm{h})$ & - & $2-35$ \\
CH_K2 & hydraulic conductivity of channel $(\mathrm{mm} / \mathrm{h})$ & $0.01-500$ & $0.01-1.5$ \\
\hline
\end{tabular}

Table 2 presents the statistical indicators obtained for the Itaeté and Argoim station after comparing model simulations with field measurements. According to the goodness-of-fit statistics, the model achieved very good performance [40]. The NSE values of $0.84-0.89$ for monthly outputs during the calibration and validation periods, respectively, suggested that the model is appropriate for simulating streamflow. The PBIAS value range from $-14 \%$ to $4 \%$, indicating excellent model performance. The $\mathrm{R}^{2}$ values were usually equal to or greater than 0.80 , indicating the model's capacity to explain most of the variance in the observed data. Finally, the RSR $<0.5$ demonstrated very good estimates for monthly flows. All goodness-of-fit indicators obtained here were also within the range of values reported in the literature for similar applications using the SWAT model $[29,44]$. 
Table 2. Statistical indicators obtained by comparing model simulations and measured monthly streamflow during the calibration (1989-1996) and validation (1997-2005) periods.

\begin{tabular}{clcccccc}
\hline \multirow{2}{*}{ Location } & \multicolumn{3}{c}{ Discharge Average $\left.\mathbf{( m}^{\mathbf{3}} / \mathbf{s}\right)$} & & Statistic & & Performance \\
\cline { 2 - 8 } & Approach & Observed & Simulated & PBIAS & RSR & $\mathbf{R}^{\mathbf{2}}$ & $\begin{array}{c}\text { Moriasi et al. } \\
\mathbf{( 2 0 0 7 )}\end{array}$ \\
\hline \multirow{2}{*}{ Itaeté } & Calibration & 48.18 & 46.13 & 4.2 & 0.40 & 0.85 & Very good \\
& Validation & 56.96 & 59.4 & -5.0 & 0.39 & 0.86 & Very good \\
& Calibration & 65.89 & 67.08 & -2.0 & 0.39 & 0.88 & Very good \\
& Validation & 72.7 & 83.28 & -14.0 & 0.32 & 0.80 & Very good \\
\hline
\end{tabular}

\subsection{Climate Projections}

\subsubsection{Raw Projections for the Baseline Period}

Figure 3 shows the average maximum and minimum temperature of observed data and baseline of the Eta-HadGEM2-ES and Eta-MIROC5 models for 1985-2005. As observed, there was a large difference between observed data and the baseline for both temperatures, indicating the necessity of bias correction before the Eta-HadGEM2-ES and Eta-MIROC5 models could be considered as reliable input data to the SWAT model. The monthly differences between models were very small, though.
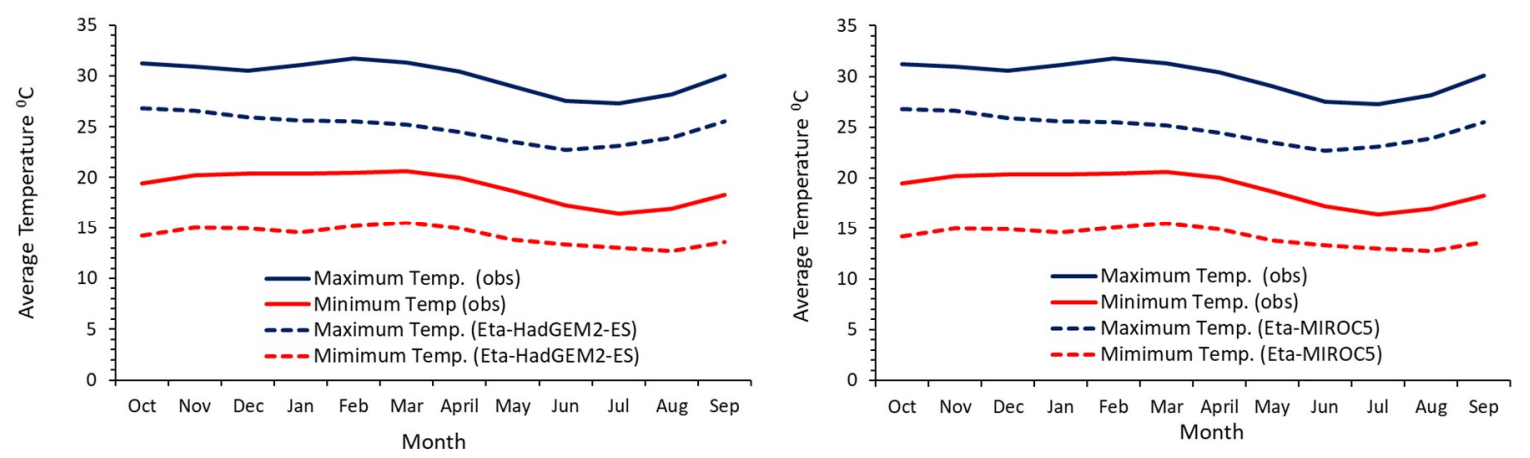

Figure 3. Spatial averaged maximum and minimum surface air temperatures for the observed and baseline data of the Eta-HadGEM2-ES (left) and Eta-MIROC5 (right) models for 1985-2005.

Figure 4 portrays the hydrological annual average precipitation of the observed data and baseline projections from the Eta-HadGEM2-ES and Eta-MIROC5 models for 1985-2005. These averages are given for four stations shown in Figure $2 b$, which compare weather variables station between grid point and models baselines. In general, the pattern of the mean monthly rainfall is well captured by both models. However, there are considerable differences between observed data and models baseline scenarios, which likewise indicate the occurrence, among others, of systematic errors and the need for bias correction. The Eta-HadGEM2-ES baseline model underestimated precipitation values in all selected stations (Figure 4), while the Eta-MIROC5 baseline model showed a tendency to overestimate precipitation values in the selected points for several months of the year (Figure 4). For both models, the peak of precipitation occurred during February and March, while observed data showed the corresponding peaks during November and December. 
(A)

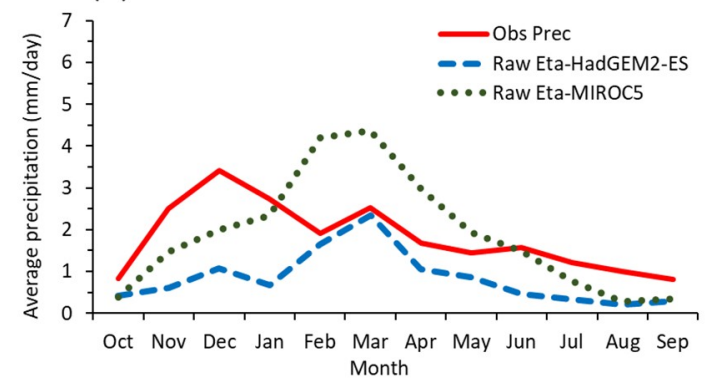

(C)

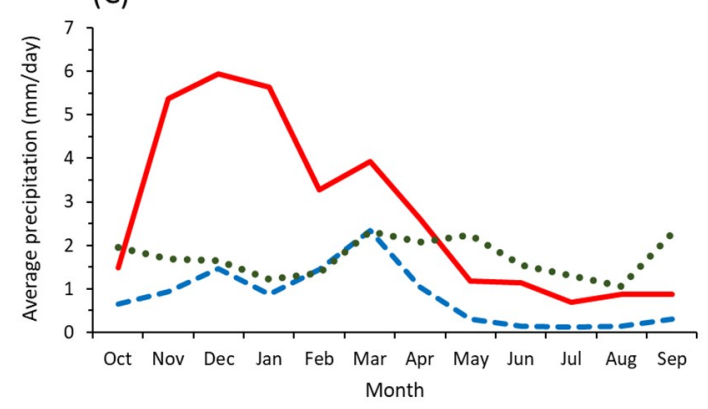

(B)

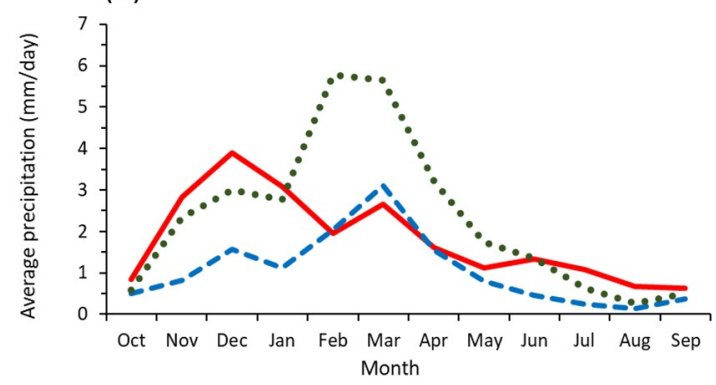

(D)

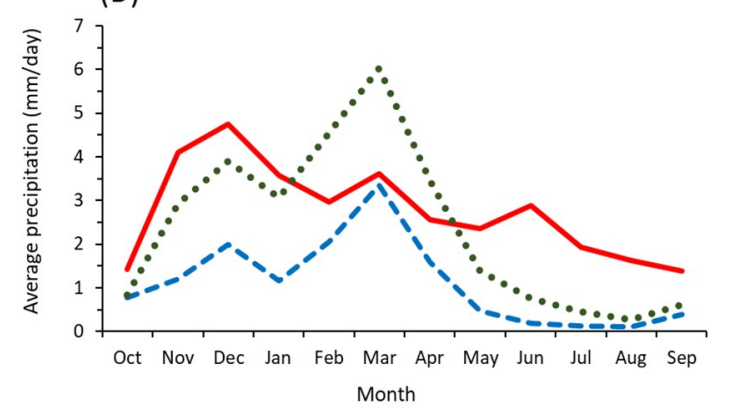

Figure 4. Average daily precipitation for observed and baseline data of the Eta-HadGEM2-ES and Eta-MIROC5 models for 1985-2005 at four stations (A, B, C, D) shown in Figure 2b.

\subsubsection{Corrected Climate Projections}

Corrected Temperature Projections by Linear Scaling

Figure 5 illustrates the projected surface temperature changes for the Paraguaçu watershed for 2020-2040 when compared to 1985-2005. For maximum (Figure 5a,b) and minimum (Figure 5c,d) temperatures, the Eta-HadGEM2-ES model showed, respectively, an average increase of 0.62 and $0.69^{\circ} \mathrm{C}$ for RCP 4.5 and 0.86 and $0.54{ }^{\circ} \mathrm{C}$ for RCP 8.5. Also, the Eta-MIROC5 model showed higher maximum and minimum temperature increase than the Eta-HadGEM2-ES model. The average of both models showed an increase of the maximum and minimum temperatures of 0.85 and $1.5^{\circ} \mathrm{C}$ for RCP 4.5, and 0.8 and $1.0^{\circ} \mathrm{C}$ for RCP 8.5, respectively. Similar values are reported in Chou et al. [24], with an increase in maximum and minimum temperature for $\mathrm{NE}$ Brazil of about $1.5^{\circ} \mathrm{C}$ in both $\mathrm{RCP}$ for 2011-2040.

Corrected Precipitation Projections by Linear Scaling and Distribution Mapping

The range of the precipitation correction factors are shown in Figure 6. These factors represent the ratio between the mean monthly observed precipitation and the mean monthly precipitation estimated by the RCMs for the controlled or historical period (Eta-HadGEM2-ES and Eta-MIROC5) for each point in the grid. The largest correction factors values are found for the period from May to August, corresponding to low precipitation months, while the largest amplitudes are found from June to August. For example, in June and August, most grid points present a correction factor between 3.5 and 8.5 and between 2.5 and 4.2, respectively. In addition, the large range of the correction factors also show that the precipitation variability in the watershed and the correction factor are dependent on the location.

The correction factors of the Eta-HadGEM2-ES model are usually higher than the Eta-MIROC5 ones, meaning that the original precipitation estimates from the former model are lower than the latter one. According to Chou et al. [24], the annual precipitation cycles in Eta simulations driven by HadGEM2-ES produces less precipitation than the MIROC5 in the rainy season, and generally more in the dry season. 
(a)
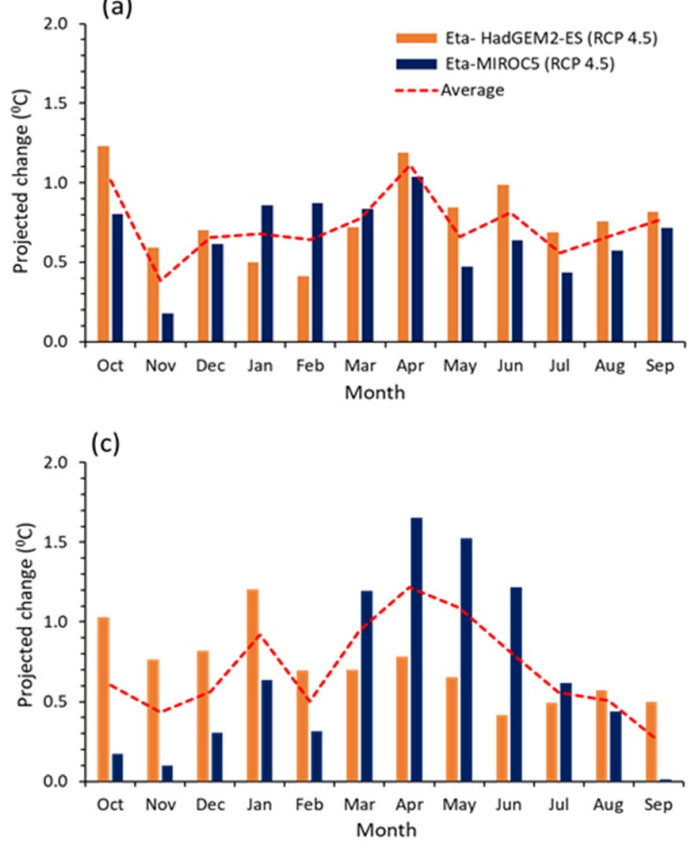
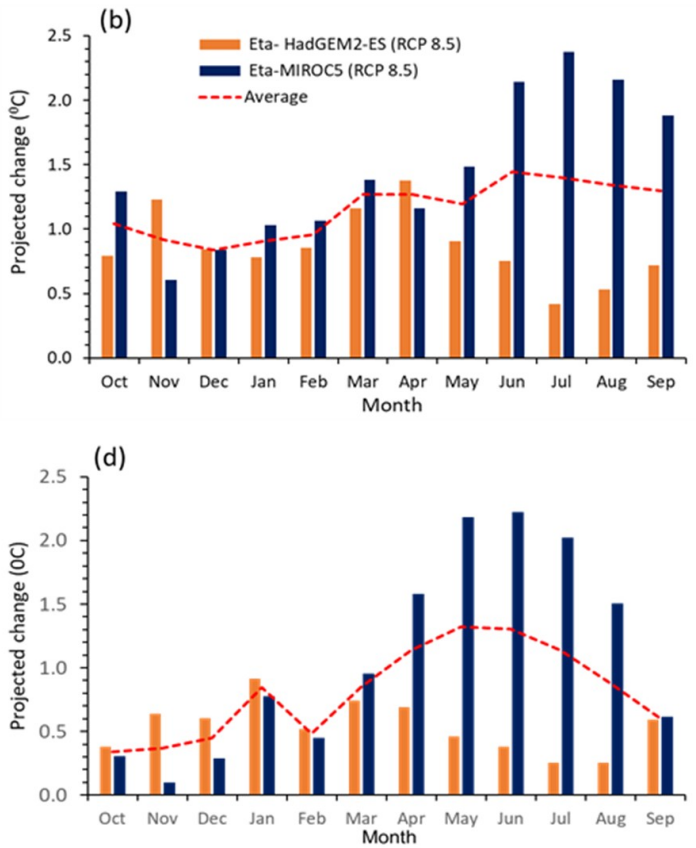

Figure 5. Projected maximum ((a) and (b)) and minimum ((c) and (d)) surface air temperature changes given by the Eta-HadGEM2-ES and Eta-MIROCS models for the RCP 4.5 ((a) and (c)) and 8.5 ((b) and (d)) scenarios for 2020-2040 (baseline: 1985-2005) in the Paraguaçu watershed.
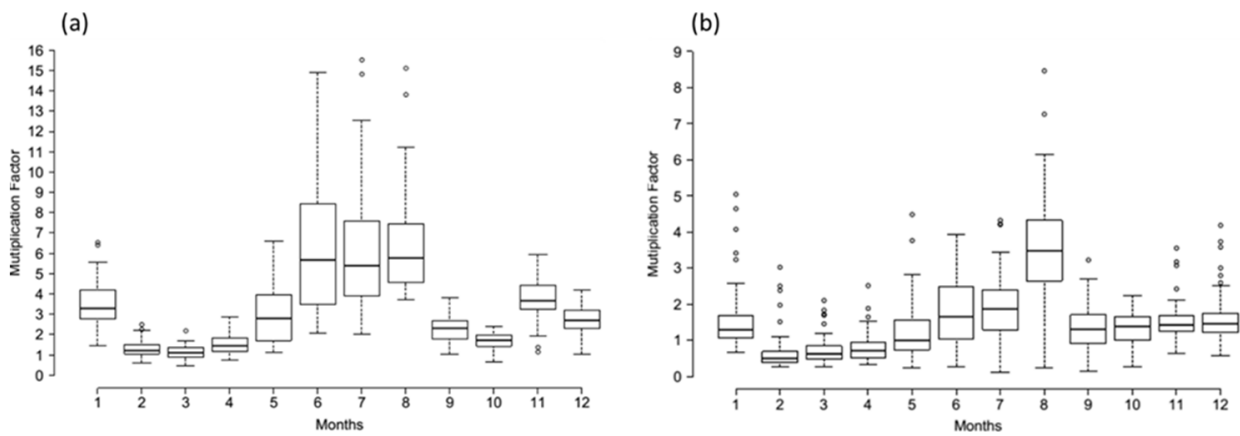

Figure 6. The range of values for the correlation factors (a) Eta-Hadgem2-ES and (b) Eta-MIROC5, respectively.

Figure 7 shows the Gamma distribution adjustment of the baseline model (1985-2005) for daily precipitation of the Eta-HadGEM2-ES and Eta-MIROC5 models. The baselines of the models (black and blue lines) were shifted towards the gamma distribution of the observations (red line) in the four points of the grid (A-D). The figure also shows the accumulated probability of the daily precipitation, where $65 \%$ of the time the rain was equal to zero for both models. The analysis showed that the method is capable of correcting systematic errors. However, precipitation values below $5 \mathrm{~mm} /$ day were not adequately adjusted in the Eta-HadGEM2-ES model (Figure 7), probably because the model baseline contained many drizzly days or more drier days than the observed values, which did not happen with Eta-MIROC5. The results indicate that the quality of the adjustment of the baseline precipitation data is strongly dependent on the choice of correction algorithm (LS or DM), as reported by Teutschbein and Seibert [18].

Figure 8 shows the average monthly precipitation values obtained by applying both bias correction methods (LS and DM) to the Eta_HadGEM2-ES and Eta-MIROC5 results. Bias were found to vary substantially depending on the catchment location when using both correction methods. Figure 8 shows a strong tendency for the HadGEM2-ES model corrected by DM method to fail in simulating low precipitation values (June to September) at points A, B and D. The same outcome was not observed 
for bias correction LS. According to Fang et al. [45], the high frequency of drizzly days in a time series distorts the baseline precipitation distribution. In such cases, the best fit can be obtained by arranging data by frequency. This will assure an adequate performance of DM in situations with more modeled than observed dry days [46].
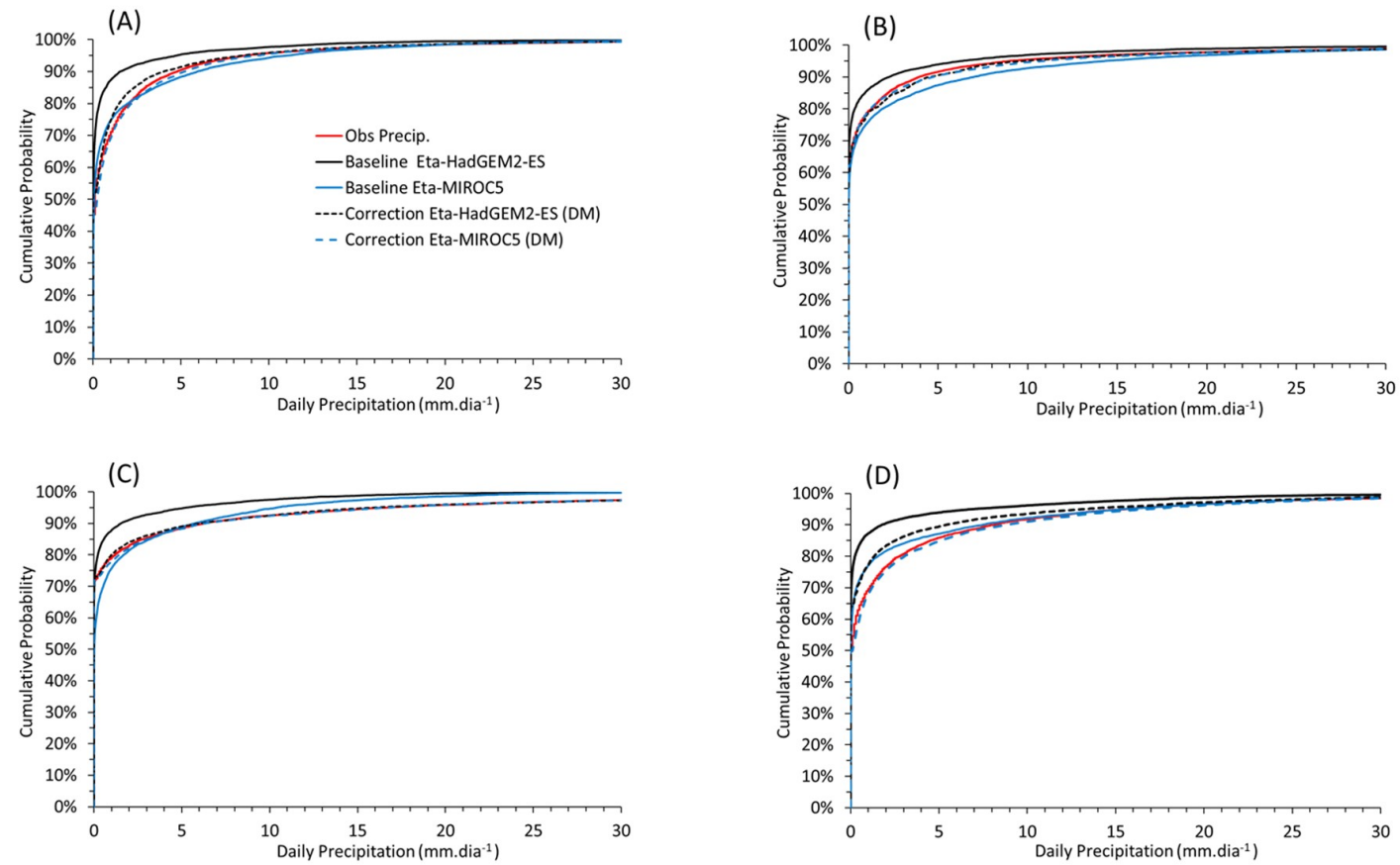

Figure 7. Gamma distribution of RCM-simulated (Eta-HadGEM2-ES and Eta-MIROC5) daily precipitation of baseline (black and blue lines) and observations at four points of the grid (A-D) for 1985-2005.

(A)

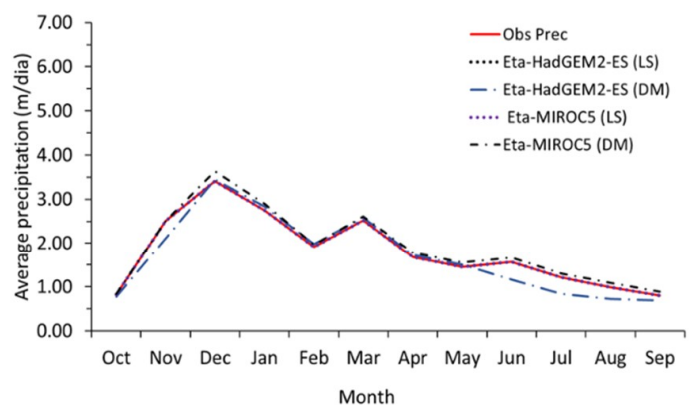

(C)

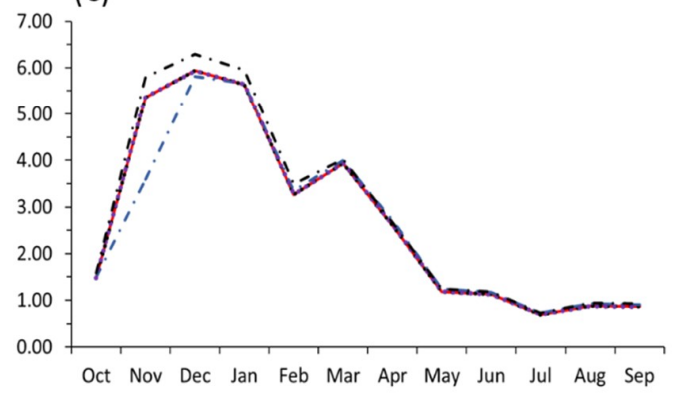

(B)

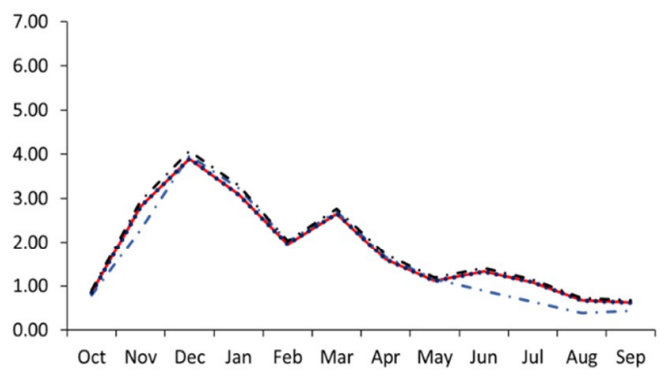

(D)

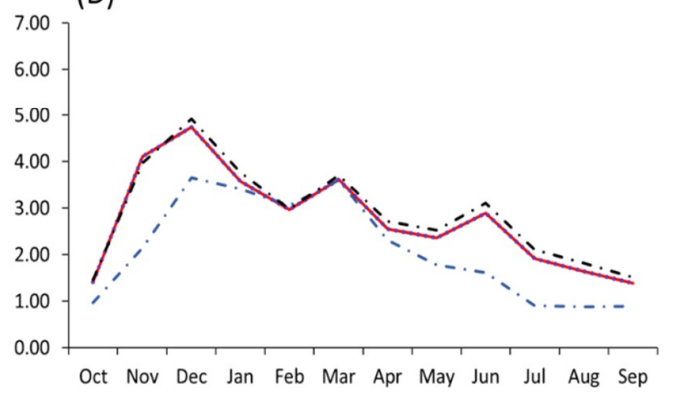

Figure 8. Average monthly precipitation for the Eta_Hadgen2-ES and Eta-MIROC5 models with bias correction linear scaling (LS) and distribution mapping (DM) at four stations of the grid (A-D) for 1985-2005. 


\subsection{Effect of Bias Correction on the Baseline Streamflow}

Table 3 compares the results of the SWAT model for the Argoim hydrometric station with inputs from RCMs following different bias corrections. The Eta-HadGEM2-ES (LS and DM) model output resulted in an underestimation of the minimum streamflow simulated by the SWAT model. Mean error was about $69 \%$ and $80 \%$ for LS and DM, respectively. On the other hand, Eta-MIROC5 LS and Eta-MIROC5 DM overestimated the minimum flow by $32 \%$ and $24 \%$, respectively. The results also indicated an overestimation of the maximum flow in $68 \%, 27 \%$, and $8 \%$ for Eta-HadGEM2-ES (LS), Eta-MIROC5 LS and Eta-MIROC5 DM, respectively, and an underestimation in $4 \%$ for Eta-HadGEM2-ES (DM). The Q90 was overestimated by $58 \%$ and $18 \%$ when using outputs from the Eta-HadGEM2-ES and Eta-MIROC5 models corrected by the LS method, while the Eta-HadGEM2-ES DM outputs underestimated that parameter by $24 \%$. Our results demonstrate that the simulated streamflow was substantially improved by applying a correction algorithm, considerably reducing monthly mean streamflow deviations of more than $100 \%$. The Eta-MIROC5 corrected by distribution mapping (DM) yielded better results for hydrological extreme simulations.

Table 3. Statistical indicators of simulated streamflow in Argoim for the baseline (1985-2005) and bias-corrected precipitation given by the Eta-HadGEM2-ES and Eta-MIROC5 climate models.

\begin{tabular}{cccccccc}
\hline \multirow{2}{*}{ Statistic Parameters } & \multirow{2}{*}{$\begin{array}{c}\text { Model } \\
\left.\mathbf{( m}^{\mathbf{3}} \mathbf{/ s}\right)\end{array}$} & \multicolumn{3}{c}{ Eta-HadGEM2-ES } & \multicolumn{3}{c}{ Eta-MIROC5 } \\
\cline { 3 - 8 } & & Baseline & LS & DM & Baseline & LS & DM \\
\hline Minimum flow & 3.1 & 0.01 & 0.98 & 0.62 & 3.3 & 4.2 & 3.9 \\
Maximum flow & 826.4 & 288.50 & 1391.0 & 792.9 & 549.5 & 1047.5 & 889.8 \\
Average flow & 77.0 & 15.67 & 109.0 & 44.3 & 88.6 & 93.1 & 85.3 \\
Q10 & 182.5 & 38.12 & 277.6 & 109.5 & 200.5 & 238.7 & 203.0 \\
Q90 & 8.5 & 1.0 & 13.4 & 6.5 & 10.26 & 10.0 & 8.4 \\
\hline
\end{tabular}

Figure 9 shows the monthly simulated streamflow for the hydrological year using the outputs of the Eta-HadGEM2-ES and Eta-MIROC5 model as inputs to SWAT, as well as the respective individual maximum exceedance curves. The RCM baseline and Eta-HadGEM2-ES corrected by the DM method were unable to simulate streamflow ( $p<0.05$ in the Wilcoxon rank), with the comparison between observed and modeled streamflow yielding significant deviations.

The monthly mean streamflow using the Eta-HadGEM2-ES model projections as inputs was underestimated by $75 \%$ (mean) from October to January, even after bias correction by the DM method (Figure 8). On the other hand, the Eta-HadGEM2-ES LS method overestimated monthly mean flow by $44 \%$ (mean). Regarding the Eta-MIROC5 (LS and DM), the simulated monthly mean showed a different behavior when compared to the Eta-HadGEM2-ES model. The LS and DM methods overestimated flow by $33 \%$ and $6 \%$ flow during the same period (October to January), respectively. The overestimated flow by the LS method between October and January may have been due to the presence of correlation factor outliers.

The maximum exceedance curve is one of the tools to determine water availability in a river basin (Figure 9(a1,b1)). Flow duration curves showed that the Eta-HadGEM2-ES model corrected by the DM method persistently underestimated flow. A contrasting scenario was observed for the Eta-MIROC5 model. The Eta-MIROC5 model produced fewer reductions in the annual precipitation when compared to Eta-HadGEM2-ES and, therefore, possible fewer impacts on streamflow [23]. Considering the dispersion in the Eta-Hadgem2-ES (DM) discharge curves, this method of correction should not be considered for simulating streamflow based on climate change projections. 
(a)

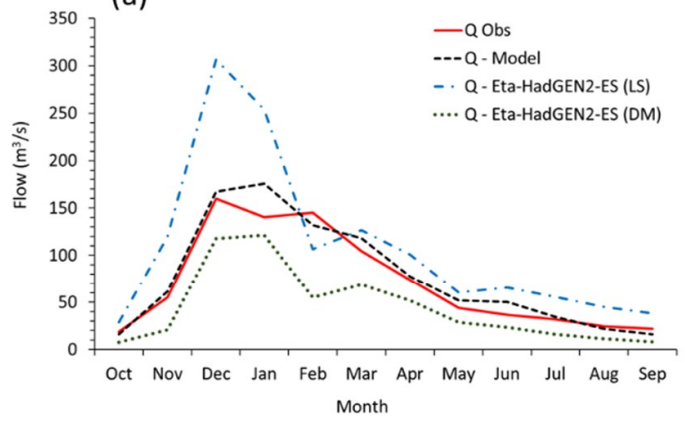

(a1)

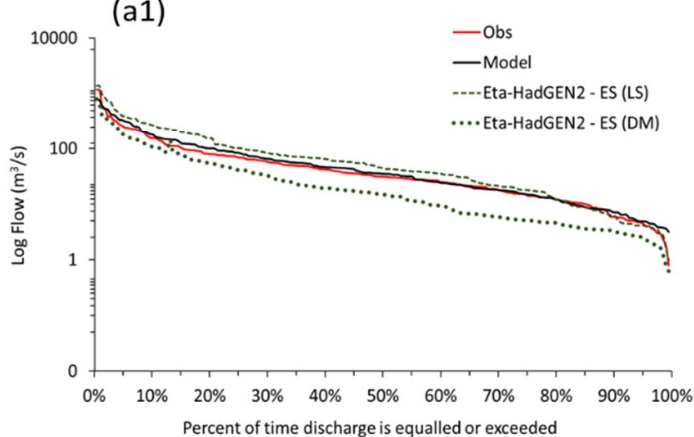

(b)

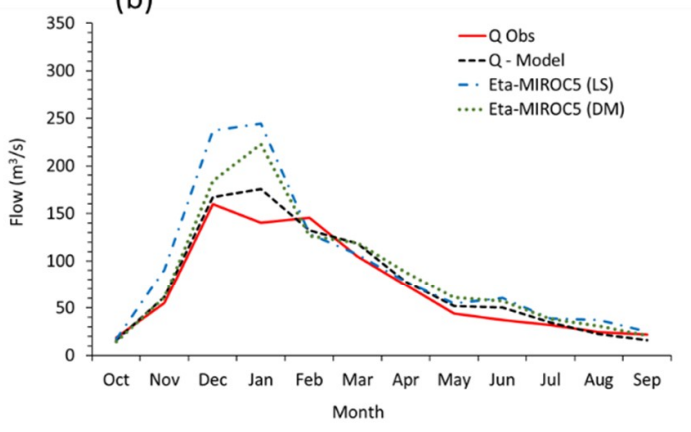

(b1)

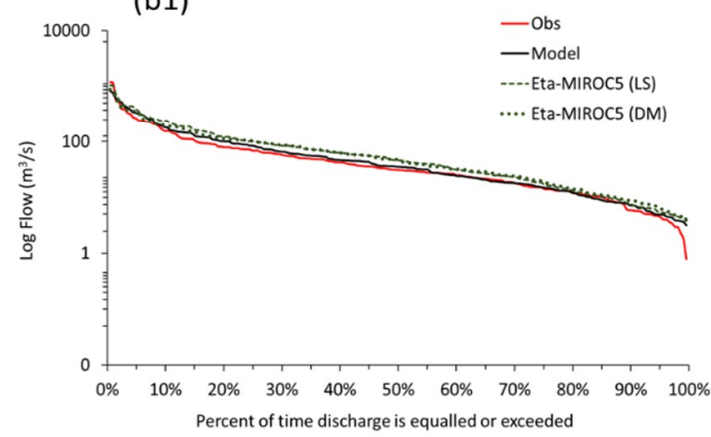

Figure 9. Simulated monthly average streamflow (top) and individual the maximum exceedance curves (bottom) in Argoim with inputs from the Eta-HadGEM2-ES (a,a1) and Eta-MIROC5 (b,b1) models for 1989-2005 (LS, linear scaling; DM, distribution mapping).

\subsection{Climate Change Impact on Streamflow}

Based on the hypothesis that the processes of generation of the systematic errors of the variables (precipitation, maximum and minimum temperatures) occur similarly for the reference and future periods, the adjustment obtained for the reference period was applied to the precipitation values generated by the Eta-HadGEM2-ES and Eta-MIROC5 models for baseline and future projections (2020-2040) of RCPs 4.5 and 8.5 .

The change in the percentage of streamflow as projected by different climate models and bias-corrected methods is summarized in Table 4. The streamflow resulting from Eta-MIROC5 (LS) projections varied from $-4 \%$ to $-35 \%$ from March to September under RCP 4.5 , and decreased by more than 45\% under the RCP 8.5 scenario. However, the Eta-MIROC5 (DM) showed an increase of over 75\% under both RCP scenarios. Oliveira et al. [47] assessed the impacts of climate change on the Grande river basin headwater region streamflow, Southeast Brazil, using also the Eta-HadGEM-ES and Eta-MIROC5 models as inputs to the SWAT model. The results showed streamflow reductions varying from $41 \%$ to $56 \%$ for the Eta-HadGEM2-ES for both RCP 4.5 and 8.5 scenarios for 2007-2040. For the Eta-MIROC5, the same reduction was found for RPC 4.5, while for the RCP 8.5 streamflow reduction varied from $14.6 \%$ to $29 \%$.

Although the DM method showed a good fit to observed data (e.g., Eta-MIROC5), results showed that DM disfigured the results when applied to future scenarios. According to Themeßl et al. [46] these impacts can be explained by the combination of two factors: a magnitude-dependent error correction functions, thus low and high quantities are corrected differently; and a trend in the underlying data, thus uncorrected future periods feature a significantly changed of the probability density function to the respective baseline. 
Table 4. Percentage change in monthly average discharge for RCP 4.5 and RCP 8.5 scenarios.

\begin{tabular}{|c|c|c|c|c|c|c|c|c|c|c|c|c|c|}
\hline Month & & October & November & December & January & February & March & April & May & June & July & August & September \\
\hline Baseline Model * & & 28.05 & 51.63 & 110.41 & 112.07 & 126.42 & 175.46 & 153.30 & 97.00 & 73.68 & 55.39 & 41.64 & 38.73 \\
\hline Baseline LS * & & 16.71 & 90.44 & 237.14 & 244.38 & 128.35 & 106.93 & 77.92 & 54.42 & 60.25 & 38.41 & 36.90 & 24.87 \\
\hline Baseline DM * & & 14.13 & 61.09 & 184.25 & 222.87 & 126.56 & 119.01 & 87.97 & 60.95 & 57.20 & 37.85 & 30.94 & 20.88 \\
\hline \multicolumn{14}{|c|}{ \% change discharge under RCP 4.5 (2020-2040) } \\
\hline Eta-MIROC5 & LS & $14 \%$ & $40 \%$ & $-35 \%$ & $-2 \%$ & $7 \%$ & $-14 \%$ & $-4 \%$ & $-5 \%$ & $-32 \%$ & $-27 \%$ & $-33 \%$ & $-31 \%$ \\
\hline Eta-MIROC5 & $\mathrm{DM}$ & $362 \%$ & $264 \%$ & $90 \%$ & $153 \%$ & $228 \%$ & $213 \%$ & $219 \%$ & $229 \%$ & $186 \%$ & $233 \%$ & $212 \%$ & $242 \%$ \\
\hline \multicolumn{14}{|c|}{ \% change discharge under RCP 8.5 (2020-2040) } \\
\hline Eta-MIROC5 & LS & $-75 \%$ & $-54 \%$ & $-49 \%$ & $-48 \%$ & $-46 \%$ & $-61 \%$ & $-67 \%$ & $-64 \%$ & $-73 \%$ & $-72 \%$ & $-71 \%$ & $-69 \%$ \\
\hline Eta-MIROC5 & $\mathrm{DM}$ & $186 \%$ & $84 \%$ & $76 \%$ & $89 \%$ & $160 \%$ & $135 \%$ & $124 \%$ & $136 \%$ & $116 \%$ & $146 \%$ & $126 \%$ & $149 \%$ \\
\hline Baseline Model ${ }^{*}$ & & 4.24 & 3.16 & 30.45 & 16.12 & 15.93 & 50.59 & 34.27 & 11.65 & 8.04 & 5.88 & 4.06 & 3.52 \\
\hline Baseline LS * & & 28.52 & 119.79 & 306.71 & 253.88 & 106.92 & 126.71 & 101.09 & 60.11 & 65.69 & 55.47 & 45.24 & 38.23 \\
\hline Baseline DM* & & 7.84 & 20.54 & 117.81 & 121.51 & 55.28 & 68.64 & 52.08 & 28.44 & 23.25 & 16.23 & 11.50 & 8.20 \\
\hline \multicolumn{14}{|c|}{ \% change discharge under RCP 4.5 (2020-2040) } \\
\hline Eta-HadGEM2-ES & LS & $-72 \%$ & $-60 \%$ & $-82 \%$ & $-69 \%$ & $-43 \%$ & $-61 \%$ & $-71 \%$ & $-69 \%$ & $-55 \%$ & $-65 \%$ & $-61 \%$ & $-74 \%$ \\
\hline Eta-HadGEM2-ES & DM & $-91 \%$ & $-86 \%$ & $-91 \%$ & $-77 \%$ & $-50 \%$ & $-71 \%$ & $-83 \%$ & $-81 \%$ & $-77 \%$ & $-79 \%$ & $-77 \%$ & $-81 \%$ \\
\hline \multicolumn{14}{|c|}{ \% change discharge under RCP 8.5 (2020-2040) } \\
\hline Eta-HadGEM2-ES & LS & $-45 \%$ & $9 \%$ & $-81 \%$ & $-80 \%$ & $-70 \%$ & $-90 \%$ & $-94 \%$ & $-84 \%$ & $-42 \%$ & $18 \%$ & $419 \%$ & $-20 \%$ \\
\hline Eta-HadGEM2-ES & DM & $-41 \%$ & $4 \%$ & $-83 \%$ & $-80 \%$ & $-62 \%$ & $-87 \%$ & $-92 \%$ & $-77 \%$ & $-63 \%$ & $-44 \%$ & $256 \%$ & $17 \%$ \\
\hline
\end{tabular}


Regarding Eta-HadGEM2-ES (LS and DM), the hydrological simulation projected a reduction in the monthly streamflow between $40 \%$ and $80 \%$ for the years $2020-2040$ on both scenarios when compared with baseline, except for month July and August in RCP 8.5. These results are according to Alvarenga et al. [48] for southeastern Brazil. The authors used the Distributed Hydrology Soil Vegetation (DHSVM) hydrological model and the Eta-HadGEM2-ES climate model (RCP 8.5 scenario) for 2011-2040, obtaining a reduction in monthly streamflow between $50 \%$ and $60 \%$. The relative decrease in discharge suggests that the available streamflow was not sufficient to meet the current demand for water resources.

\section{Conclusions}

The calibrated/validated SWAT model was able to reproduce long-term monthly streamflow in the Paraguaçu watershed. The goodness-of-fit indicators resulted in NSE values higher 0.84 monthly streamflow, indicating an excellent result on the monthly scale. This study confirms previous studies showing the importance of bias correction of RCM simulated precipitation time series. The bias correction methods (linear scaling and distribution mapping) were able to correct bias from the baseline models. However, the simulations of monthly mean streamflow with Eta-HadGEM2-ES was underestimated by $42 \%$ in the baseline period, after bias correction by the distribution mapping method.

The climate projections for 2020-2040 showed significant reductions of mean monthly streamflow, under both RCP 4.5 and 8.5, negatively impacting the flow and showing the high vulnerability of the region concerning water supply in the future. The Eta-HadGEM2-ES (LS) indicated more critical results for both RCP than Eta-MIROC5 (LS), while the bias correction method distribution mapping $(\mathrm{DM})$ is distorted when applied to future scenarios.

The results of the study highlight the need for a good performance of the hydrological and climate models for climate impact studies applications. Nevertheless, the choice of a bias correction algorithm plays also a significant role when assessing climate model estimates and their applicability to hydrological modelling.

Author Contributions: C.A.S.S. set up the model, ran the simulations, and wrote the paper. The other authors made revisions and improvements to the draft.

Funding: MARETEC acknowledges ERDF Funds of the Competitiveness Factors Operational ProgrammeCOMPETE, and national funds from the Fundação para a Ciência e Tecnologia (FCT) (Project UID/EEA/50009/2019). T.B. Ramos was funded by FCT funds (SFRH/BPD/110655/2015).

Acknowledgments: Acknowledgements are due to the Institute Federal of Bahia. The authors wish to thank to the Eta climate group from CPTEC/INPE for producing and making available their RCM outputs.

Conflicts of Interest: The authors declare no conflict of interest.

\section{References}

1. Intergovernmental Panel on Climate Change. Climate Change 2013: The Physical Science Basis. Contribution of Working Group I to the Fifth Assessment Report of the Intergovernmental Panel on Climate Change; Cambridge University Press: Cambridge, UK; New York, NY, USA, 2013.

2. Zhang, Y.; You, Q.; Chen, C.; Ge, J. Impacts of climate change on streamflows under rcp scenarios: A case study in xin river basin, china. Atmospheric Res. 2016, 178-179, 521-534. [CrossRef]

3. Mishra, Y.; Nakamura, T.; Babel, M.S.; Ninsawat, S.; Ochi, S. Impact of climate change on water resources of the bheri river basin, nepal. Water 2018, 10, 220. [CrossRef]

4. Taye, M.T.; Willems, P.; Block, P. Implications of climate change on hydrological extremes in the blue nile basin: A review. J. Hydrol. Reg. Stud. 2015, 4, 280-293. [CrossRef]

5. Almeida, C.; Ramos, T.B.; Segurado, P.; Branco, P.; Neves, R.; Oliveira, R.P. Water quantity and quality under future climate and societal scenarios: A basin-wide approach applied to the Sorraia River, Portugal. Water 2018, 10, 1186. [CrossRef] 
6. Jiménez Cisneros, B.; Oki, T.; Arnell, N.W.; Benito, G.; Cogley, J.G.; Doll, P.; Jiang, T.; Mwakalila, S.S. Freshwater resources. In Climate Change 2014: Impacts, Adaptation, and Vulnerability. Part A: Global and Sectoral Aspects; Contribution of Working Group II to the Fifth Assessment Report of the Intergovernmental Panel of Climate Change; Cambridge University Press: Cambridge, UK; New York, NY, USA, 2014; pp. 229-269.

7. IPCC. Summary for Policymakers. In Climate Change 2013: The Physical Science Basis. Contribution of Working Group I to the Fifth Assessment Report of the Intergovernmental Panel on Climate Change; Stocker, T.F., Qin, D., Plattner, G.-K., Tignor, M., Allen, S.K., Boschung, J., Nauels, A., Xia, Y., Bex, V., Midgley, P.M., Eds.; Cambridge University Press: Cambridge, UK, 2013.

8. Brazilian Institute of Geography and Statistics (IBGE). Available online: https://ww2.ibge.gov.br/home/ estatistica/populacao/censo2010/ (accessed on 15 April 2017).

9. Brito, S.S.B.; Cunha, A.P.M.A.; Cunningham, C.C.; Alvalá, R.C.; Marengo, J.A.; Carvalho, M.A. Frequency, duration and severity of drought in the semiarid northeast brazil region. Int. J. Clim. 2018, 38, 517-529. [CrossRef]

10. Marengo, J.A.; Alves, L.M.; Alvala, R.C.S.; Cunha, A.P.; Brito, S.; Moraes, O.L.L. Climatic characteristics of the 2010-2016 drought in the semiarid northeast brazil region. Anais da Academia Brasileira de Ciências 2018, 90, 1973-1985. [CrossRef]

11. Zhang, D.; Chen, X.; Yao, H.; Lin, B. Improved calibration scheme of swat by separating wet and dry seasons. Ecol. Model. 2015, 301, 54-61. [CrossRef]

12. Zhang, X.; Xu, Y.-P.; Fu, G. Uncertainties in swat extreme flow simulation under climate change. J. Hydrol. 2014, 515, 205-222. [CrossRef]

13. Santos, A.M.; Galvincio, J.D.; Moura, M.S.B. Mudanças climáticas e o escoamento superficial na bacia hidrográfica do rio goiana-Pernambuco. Investigaciones Geográficas, Boletín del Instituto de Geografía 2013, 2013, 51-65.

14. Kwon, H.H.; de Assis de Souza Filho, F.; Block, P.; Sun, L.; Lall, U.; Reis, D.S., Jr. Uncertainty assessment of hydrologic and climate forecast models in northeastern brazil. Hydrol. Process. 2012, 26, 3875-3885. [CrossRef]

15. Githui, F.; Gitau, W.; Mutua, F.; Bauwens, W. Climate change impact on swat simulated streamflow in western kenya. Int. J. Clim. 2009, 29, 1823-1834. [CrossRef]

16. De Mello, E.L.; Oliveira, F.A.; Pruski, F.F.; Figueiredo, J.C. Efeito das mudanças climáticas na disponibilidade hídrica da bacia hidrográfica dio rio paracatu. Engenharia Agrícola 2008, 28, 635-644. [CrossRef]

17. Zhang, Y.G.; Su, F.G.; Hao, Z.C.; Xu, C.Y.; Yu, Z.B.; Wang, L.; Tong, K. Impact of projected climate change on the hydrology in the headwaters of the yellow river basin. Hydrol. Process. 2015, 29, 4379-4397. [CrossRef]

18. Teutschbein, C.; Seibert, J. Bias correction of regional climate model simulations for hydrological climate-change impact studies: Review and evaluation of different methods. J. Hydrol. 2012, 456-457, 12-29. [CrossRef]

19. Krysanova, V.; Donnelly, C.; Gelfan, A.; Gerten, D.; Arheimer, B.; Hattermann, F.; Kundzewicz, Z.W. How the performance of hydrological models relates to credibility of projections under climate change. Hydrol. Sci. J. 2018, 63, 696-720. [CrossRef]

20. Santos, C.A.S.; Almeida, C.; Ramos, T.B.; Rocha, F.A.; Oliveira, R.; Neves, R. Using a hierarchical approach to calibrate swat and predict the semi-arid hydrologic regime of northeastern brazil. Water 2018, 10, 1137. [CrossRef]

21. Neitsch, S.L.; Arnold, J.C.; Kiniry, J.R.; Williams, J.R.; King, K.W. Soil and Water Assessment Tool Theoretical Documentation. Version 2000; TR-192, Technical Report; Texas Water Resources Institute: College Station, TX, USA, 2002.

22. KlemeŠ, V. Operational testing of hydrological simulation models. Hydrol. Sci. J. 1986, 31, 13-24. [CrossRef]

23. Chou, S.C.; Lyra, A.; Mourão, C.; Dereczynski, C.; Pilotto, I.; Gomes, J.; Bustamante, J.; Tavares, P.; Silva, A.; Rodrigues, D.; et al. Evaluation of the eta simulations nested in three global climate models. Am. J. Clim. Chang. 2014, 03, 438-454. [CrossRef]

24. Chou, S.C.; Lyra, A.; Mourão, C.; Dereczynski, C.; Pilotto, I.; Gomes, J.; Bustamante, J.; Tavares, P.; Silva, A.; Rodrigues, D.; et al. Assessment of climate change over south america under rcp 4.5 and 8.5 downscaling scenarios. Am. J. Clim. Chang. 2014, 03, 512-527. [CrossRef] 
25. Collins, W.J.; Bellouin, N.; Doutriaux-Boucher, M.; Gedney, N.; Halloran, P.; Hinton, T.; Hughes, J.; Jones, C.D.; Joshi, M.; Liddicoat, S.; et al. Development and evaluation of an earth-system model-Hadgem2. Geosci. Model Dev. 2011, 4, 1051-1075. [CrossRef]

26. Watanabe, M.; Suzuki, T.; O'ishi, R.; Komuro, Y.; Watanabe, S.; Emori, S.; Takemura, T.; Chikira, M.; Ogura, T.; Sekiguchi, M.; et al. Improved climate simulation by miroc5: Mean states, variability, and climate sensitivity. J. Clim. 2010, 23, 6312-6335. [CrossRef]

27. Arnold, J.G.; Srinivasan, R.; Muttiah, R.S.; Williams, J.R. Large area hydrologic modeling and assessment-Part 1: Model development. J. Am. Water Resour. 1998, 34, 73-89. [CrossRef]

28. Neitsch, S.L.; Arnold, J.G.; Kiniry, J.R.; Williams, J.R. Soil and Water Assessment Tool. Theoretical Documentation. Version 2009; Technical Report No.406; Texas Water Resources Institute: Forney, TX, USA, 2011.

29. Awotwi, A.; Kumi, M.; Jansson, P.E.; Yeboah, F.; Nti, I.K. Predicting hydrological response to climate change in the white volta catchment, west africa. J. Earth Sci. Clim. Chang. 2015, 6, 1-7.

30. Monteith, J.L. Evaporation and the Environment. Symp. Soc. Exp. Biol. 1965, 19, 205-234. [PubMed]

31. United States Department of Agriculture. Estimation of direct runoff from storm rainfall. In National Engineering Handbook; United States Department of Agriculture: Washington, DC, USA, 2004.

32. Bontemps, S.; Defourny, P.; Radoux, J.; Bogaert, E.V.; Lamarche, C.; Achard, F.; Mayaux, P.; Boettcher, M.; Brockmann, C.; Kirches, G.; et al. Globcover 2009: Product Description and Validation Report 18 February 2011. Available online: http://due.esrin.esa.int/files/GLOBCOVER2009_Validation_Report_ 2.2.pdf (accessed on 24 August 2018).

33. Embrapa. Solo Brasileiro Agora Tem Mapeamento Digital. Available online: https://www.embrapa.br/ web/portal/busca-de-noticias/-/noticia/2062813/solo-brasileiro-agora-tem-mapeamento-digital (accessed on 24 August 2018).

34. Silva, R.M.; Medeiros, I.C. Análise hidrossedimentológica em ambiente sig usando o modelo swat. Revista Internacional de Ciencia y Tecnología de la Información Geográfica 2014, 14, 211-231.

35. De Santana, S.O.; dos Santos, R.D.; Gomes, I.A.; de Jesus, R.M.; de Araujo, Q.R.; Mendonça, J.R.; Calderano, S.B.; Faria Filho, A.F. Solos da região sudeste da bahia: Atualização da legenda de acordo com o sistema brasileiro de classificação de solos; Embrapa Solos: Rio de Janeiro, Brazil, 2002.

36. Xavier, F.V. Contribuições metodológicas ao estudo da produção e distribuição espacial de sedimentos na bacia hidrográfica do rio manso, utilizando o modelo avswat. Master's Thesis, Universidade Federal de Mato Grosso, Cuiabá, Brazil, 2009.

37. Mercuri, E.G.F.; Deppe, F.; Lohmann, M.; Simões, K. Metodologia da geração de dados de entrada e aplicação do modelo swat para bacias hidrográficas brasileiras. In Anais XIV Simpósio Brasileiro de Sensoriamento Remoto; Instituto Nacional De Pesquisas Espaciais: Natal, Brasil, 2009; pp. 4773-4780.

38. Xavier, A.C.; King, C.W.; Scanlon, B.R. Daily gridded meteorological variables in brazil (1980-2013). Int. J. Clim. 2015, 2644-2659. [CrossRef]

39. Nash, J.E.; Sutcliffe, J.V. River flow forecasting through conceptual models part I-A discussion of principles. J. Hydrol. 1970, 10, 282-290. [CrossRef]

40. Moriasi, D.N.; Arnold, J.G.; Van Liew, M.W.; Bingner, R.L.; Harmel, R.D.; Veith, T.L. Model evaluation guidelines for systematic quantification of accuracy in watershed simulations. Trans. ASABE 2007, 50, 885-900. [CrossRef]

41. IPCC. Climate Change 2014: Synthesis Report. Contribution of Working Groups I, II and III to the Fifth Assessment Report of the Intergovernmental Panel on Climate Change; Core Writing Team, Pachauri, R.K., Meyer, L.A., Eds.; IPCC: Geneva, Switzerland, 2014; p. 151.

42. Bosshard, T.; Kotlarski, S.; Schär, C. Local Scenarios at Daily Resolution for Emission Scenarios a2 and rcp3pd, ch2011 Extension Series No. 1; Zurich, Switzerland, 2015; p. 12. Available online: https:/ /www.ch2011.ch/ pdf/CH2011plus_No1_Bosshard2015.pdf (accessed on 14 January 2019).

43. Lenderink, G.; Buishand, A.; Deursen, W. Estimative of future discharges of the river rhine using two scenario methodologies: Direct versus delta approach. Hydrol. Earth Syst. Sci. 2007, 11, 1145-1159. [CrossRef]

44. Nie, W.; Yuan, Y.; Kepner, W.; Erickson, C.; Jackson, M. Hydrological impacts of mesquite encroachment in the upper san pedro watershed. J. Arid Environ. 2012, 82, 147-155. [CrossRef]

45. Fang, G.H.; Yang, J.; Chen, Y.N.; Zammit, C. Comparing bias correction methods in downscaling meteorological variables for a hydrologic impact study in an arid area in china. Hydrol. Earth Syst. Sci. 2015, 19, 2547-2559. [CrossRef] 
46. Themeß1, M.J.; Gobiet, A.; Heinrich, G. Empirical-statistical downscaling and error correction of regional climate models and its impact on the climate change signal. Clim. Chang. 2011, 112, 449-468. [CrossRef]

47. De Oliveira, V.A.; de Mello, C.R.; Viola, M.R.; Srinivasan, R. Assessment of climate change impacts on streamflow and hydropower potential in the headwater region of the grande river basin, southeastern brazil. Int. J. Clim. 2017, 37, 5005-5023. [CrossRef]

48. Alvarenga, L.A.; Mello, C.R.; Colombo, A.; Cuartas, L.A.; Chou, S.C. Hydrological responses to climate changes in a headwater watershed. Ciência E Agrotecnologia 2016, 40, 647-657. [CrossRef]

(C) 2019 by the authors. Licensee MDPI, Basel, Switzerland. This article is an open access article distributed under the terms and conditions of the Creative Commons Attribution (CC BY) license (http:/ / creativecommons.org/licenses/by/4.0/). 